\title{
Species Review of Amphibian Extinction Risks in Madagascar: Conclusions from the Global Amphibian Assessment
}

\author{
FRANCO ANDREONE, ${ }^{*}$ JOHN E. CADLE, $\uparrow$ NEIL COX, $\ddagger$ FRANK GLAW, $§$ RONALD A. NUSSBAUM, ${ }^{* *}$ \\ CHRISTOPHER J. RAXWORTHY, $\dagger$ SIMON N. STUART,$\ddagger$ DENIS VALLAN, $\neq \ddagger$ \\ AND MIGUEL VENCES $\S \S$ \\ *Museo Regionale di Scienze Naturali, Via G. Giolitti, 36, I-10123 Torino, Italy, email f.andreone@libero.it \\ †Department of Herpetology, Chicago Zoological Society, 3300 Golf Road, Brookfield, IL 60513, U.S.A. \\ $\ddagger$ IUCN/SSC-CI/CABS Biodiversity Assessment Initiative, c/o Center for Applied Biodiversity Science, Conservation International, \\ 1919 M Street NW, Suite 600, Washington, D.C. 20036, U.S.A. \\ $\S Z$ Zoologische Staatssammlung, Münchhausenstrasse 21, D-81247 München, Germany \\ ** Division of Reptiles and Amphibians, Museum of Zoology, University of Michigan, Ann Arbor, MI 48109-1079, U.S.A. \\ t†Department of Herpetology, American Museum of Natural History, Central Park West at 79th Street, New York, NY 10024-5192, \\ U.S.A. \\ ‡ђUniversität Bern, Zoologisches Institut, Baltzerstrasse 6, CH-3012 Bern, and Natur-Museum Luzern, Kasernenplatz 6, CH-6003 \\ Luzern, Switzerland \\ $\S \S$ Institute of Biodiversity and Ecosystem Dynamics, Zoological Museum, Mauritskade 61, 1092 AD Amsterdam, The Netherlands
}

\begin{abstract}
We assessed the extinction risks of Malagasy amphibians by evaluating their distribution, occurrence in protected areas, population trends, habitat quality, and prevalence in commercial trade. We estimated and mapped the distribution of each of the 220 described Malagasy species and applied, for the first time, the IUCN Red List categories and criteria to all species described at the time of the assessment. Nine species were categorized as critically endangered, 21 as endangered, and 25 as vulnerable. The most threatened species occur on the High Plateau and/or have been subjected to overcollection for the pet trade, but restricted extent of occurrence and ongoing babitat destruction were identified as the most important factors influencing extinction threats. The two areas with the majority of threatened species were the northern TsaratananaMarojejy-Masoala highlands and the southeastern Anosy Mountains. The current system of protected areas includes $82 \%$ of the threatened amphibian species. Of the critically endangered species, 6 did not occur in any protected area. For conservation of these species we recommend the creation of a reserve for the species of the Mantella aurantiaca group, the inclusion of two Scaphiophryne species in the Convention on the International Trade in Endangered Species Appendix II, and the suspension of commercial collecting for Mantella cowani. Field surveys during the last 15 years reveal no pervasive extinction of Malagasy amphibians resulting from disease or other agents, as has been reported in some other areas of the world.
\end{abstract}

Key Words: IUCN, species risk categorization, species status assessment

Revisión del Riesgo de Extinción de Anfibios en Madagascar: Conclusiones de Evaluación Global de Anfibios

Resumen: Evaluamos los riesgos de extinción de anfibios malgaches mediante el análisis de su distribución, ocurrencia en áreas protegidas, tendencias poblacionales, calidad del hábitat y prevalencia en el comercio. Estimamos y mapeamos la distribución de cada una de las 220 especies descritas para Madagascary aplicamos, por primera vez, las categorías y criterios de la Lista Roja de IUCN a todas las especies descritas al momento

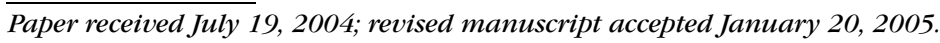

1790

Conservation Biology 1790-1802

C)2005 Society for Conservation Biology

DOI: $10.1111 / \mathrm{j} .1523-1739.2005 .00249 . \mathrm{x}$ 
de la evaluación. Nueve especies fueron clasificadas en peligro crítico, 21 como amenazadas y 25 como vulnerables. Las especies más amenazadas ocurren en High Plateau y/o ban sido sujetas a sobreexplotación para el comercio de mascotas, pero identificamos a la extensión restringida de ocurrencia y a la destrucción del bábitat como los factores que más influyen sobre las amenazas de extinción. Las mesetas de TsaratananaMarojejy-Masoala en el norte y las Montañas Anosy en el sureste fueron las dos áreas con la mayoría de especies amenazadas. El actual sistema de áreas protegidas incluye a $82 \%$ de las especies de anfibios amenazadas. De las especies en peligro crítico, 6 no ocurrieron en ninguna área protegida. Para la conservación de estas especies recomendamos la creación de una reserva para especies del grupo de Mantella aurantiaca, la inclusión de dos especies de Scaphiophryne en el Apéndice II de la Convención Internacional para el Comercio de Especies en Peligro y la suspensión de la colecta comercial de Mantella cowani. Los estudios de campo llevados a cabo en los últimos 15 años no muestran la extinción generalizada de anfibios malgaches debido a enfermedades $u$ otros agentes, como se ha registrado en algunas otras partes del mundo.

Palabras Clave: clasificación del riesgo de especies, evaluación del estatus de especies, IUCN

\section{Introduction}

The diversity and endemism of Malagasy amphibians have been highlighted in recent decades (Blommers-Schlösser \& Blanc 1991; Stuart et al. 2004), illustrating the importance of this vertebrate group to understanding evolutionary processes and in identifying conservation priorities. High rates of deforestation and general habitat degradation are among the most immediate threats to Madagascar's biota and landscapes, and it is important to review the current conservation status of endemic species and speciose groups such as amphibians, which are sensitive to environmental change (Vallan 2002, 2003).

There are four families of frogs in Madagascar: Mantellidae, Microhylidae, Ranidae, and Hyperoliidae (Glaw \& Vences 2003). Mantellidae is the most speciose group and is endemic to Madagascar and the Comoro Islands. It includes the genera Mantidactylus (90 species), Mantella (15 species), Boophis (50 species), Aglyptodactylus (3 species), and Laliostoma (1 species). Mantidactylus and Mantella show peculiar features related to reproduction, such as essential absence of amplexus (mating embrace) and nuptial pads, eggs laid outside water, and presence (in most species) of femoral glands. Species of Mantella (Vences et al. 1999) are brightly colored and show accumulation of alkaloids in the skin (Daly et al. 1996). Boophis species are arboreal frogs that lay eggs in water (Blommers-Schlösser 1979). Aglyptodactylus and Laliostoma are terrestrial and breed in temporary ponds (Vences \& Glaw 2001). Ranids include the opportunistic and widely distributed Ptychadena mascareniensis, present also in the Mascarene Islands and Seychelles, and Hoplobatrachus tigerinus, introduced to Madagascar from southern Asia (Kosuch et al. 2001). Microhylids are represented by 10 genera (and approximately 50 species) with diverse life histories (Blommers-Schlösser \& Blanc 1991): Dyscophus, Paradoxophyla, Scaphiophryne, Cophyla, Platypelis, Anodonthyla, Plethodontohyla, Madecassophryne, Rbombophryne, and Stumpffia. Finally, the only Malagasy hyperoliids are in the endemic genus Heterixalus (11 species), which inhabits grasslands and forest edges (Vences et al. 2003).

The different life-history traits of these amphibians are mirrored by their differential ecological sensitivity and conservation needs (Andreone \& Luiselli 2003). Most of the Malagasy frogs inhabit the eastern rainforest, an ecosystem that allowed the rapid diversification of some frog groups such as Boophis (Vences et al. 2002b), Mantidactylus (Andreone 2003), and cophyline microhylids (Andreone et al. 2005). The original eastern rainforest block is now severely fragmented because of deforestation in recent times (Green \& Sussman 1990), and it continues to be subject to heavy anthropogenic pressure (Vallan 2000b). As a rule, forest fragmentation has led to an impoverishment of the native amphibian fauna, although in some cases this loss of amphibian species richness is not immediately evident (Vallan et al. 2004) because species have differing sensitivities to habitat alterations (Andreone 1994). Overharvesting for the pet trade is an additional threat to the long-term survival of a number of Malagasy amphibians. Thousands of colorful frogs (e.g., Mantella, Scaphiophryne, Dyscophus species) are exported each year to Europe, North America, or Japan, where they can fetch high prices (Behra \& Raxworthy 1991). The effects of trade on natural populations are still poorly studied, and we did not consider the effects of collecting on the long-term survival of these populations (Raxworthy \& Nussbaum 2000; Andreone \& Luiselli 2003; Rabemanjara et al. 2005).

Current conservation strategies in Madagascar include identifying priority areas for threatened species or overall species diversity and including these areas in nature reserves (Ganzhorn et al. 1997; ANGAP 2001). The presence of a rich amphibian fauna or of threatened amphibian species was only rarely considered in the establishment of new protected areas because other, more "visible" taxa (e.g., lemurs, birds) were often considered a priority. Most Malagasy amphibian species occur in one 
or more protected areas. Some species, however, known as "gap species," do not occur in protected areas and are of particular concern (Rodrigues et al. 2004).

As part of the Global Amphibian Assessment (GAA, Stuart et al. 2004), we evaluated the conservation status of all described amphibians from Madagascar, based on the IUCN Red List Categories and Criteria (IUCN 2001). We summarize the results of the GAA workshop, provide updated information on species distributions, and discuss how life-history traits and other factors influence conservation assessment of amphibians. We also provide updated or new red listings for all amphibian species and highlight general patterns gleaned from our assessment.

\section{Methods}

\section{Conservation Priorities Investigation}

During the GAA workshop of 2003 we evaluated 220 amphibian species (described or in press as of December 2003) based on published data and our own unpublished information on species distributions and systematics ( Tables $1 \& 2$ ). We followed IUCN categorization rules (reported in IUCN [2001]) in which species are classified as critically endangered (CR), endangered (EN), vulnerable (VU), near threatened (NT), data deficient (DD), or least concern (LC).

To establish the threat category for each species, one of us (R.A.N.) conducted a preliminary screening of the available information regarding the distribution and threats of each species. Based on his findings, he drew a distribution map for the species and entered data on the distribution, abundance, population trends, ecology, habitat preferences, threats, utilization, conservation measures, and red-list status into the GAA database, following data standards outlined in IUCN (2001). The rest of us reviewed the data sheets compiled by R.A.N., and then at the GAA Madagascar workshop added further information and data. At the workshop we reached agreement on the data associated with each species. (The GAA data for Madagascar are publicly available from www.globalamphibian.org.) We then determined the appropriate IUCN category for each species based on these data, not on expert opinion. Localities mentioned in the text are shown in Fig. 1.

\section{Statistical Procedures and Graphical Analysis}

Spatial analyses of the species' distribution maps were performed with ESRI ArcView 3.2a Spatial Analyst extension (ESRI 2000) to determine the areas with the highest diversities of amphibian species and those areas with a high diversity of species in IUCN threatened categories. The individual digitized, multipolygon-based distribution maps were assembled to create a single shapefile that contained the distribution information for all Mala- gasy species. This shapefile was then dissolved against the species name record included in the associated attribute table, creating a single distribution polygon for each species. We then used a script to create a grid (with cell size of $0.1^{\circ}$ ) from each polygon. We overlaid these grids and calculated the value for the number of species present within each cell. We then created two speciesrichness maps for all species, and a combined map of species density for the three $(\mathrm{CR}+\mathrm{EN}+\mathrm{VU})$ highest IUCN threat categories.

\section{Results}

\section{Species Summary}

There were 55 species in threatened categories, corresponding to $25 \%$ of the Malagasy amphibians (Tables 1 $\& 2$ ). Of these, 13 species are collected and exported in pet trade and 11 are listed in CITES (Convention on International Trade in Endangered Species of Wild Fauna and Flora) Appendix II (www.cites.org/eng/appendices. shtml). Two species classified as threatened and involved in trade but not listed in CITES are Scapbiopbryne boribory and $S$. marmorata. The remaining species were not categorized in the three highest threat categories, although some of them were classified as NT. These include two species that are sometimes in trade (Mantella laevigata and Scaphiophryne madagascariensis) and one species that is the only Malagasy amphibian currently listed in CITES Appendix I, the tomato frog (Dyscopbus antongili). Species assigned to the DD category included poorly known species.

\section{Critically Endangered Species}

We categorized nine species as CR: Boophis williamsi, Mantella aurantiaca, M. cowani, M. expectata, M. milotympanum, M. viridis, Mantidactylus pauliani, Scapbiopbryne gottlebei, and Stumpffia belenae (Fig. 2).

We listed Boophis williamsi as CR based on its extent of occurrence (EOO) of $<100 \mathrm{~km}^{2}$ and its area of occupancy (AOO) of $<10 \mathrm{~km}^{2}$. Since its description in 1974 the only known population of this species is a single unprotected site in the Ankaratra Massif at $2100 \mathrm{~m}$ of elevation (Vences et al. 2002b). The extent and quality of habitat in this area continue to decline. B. williamsi may have lived originally in montane rainforest, but it is now restricted to high-elevation grasslands with relict montane forest. It breeds in fast-flowing mountain streams and inhabits nearby degraded areas. This habitat is annually burned and is subject to extensive overgrazing and cultivation (potato fields). The species appears to be very rare and was only occasionally encountered.

Mantella aurantiaca was categorized CR based on its AOO of $<10 \mathrm{~km}^{2}$. Its distribution is now severely fragmented. Although localized, the population density of $M$. 
Table 1. Status ${ }^{a}$ of globally threatened Madagascan amphibians.

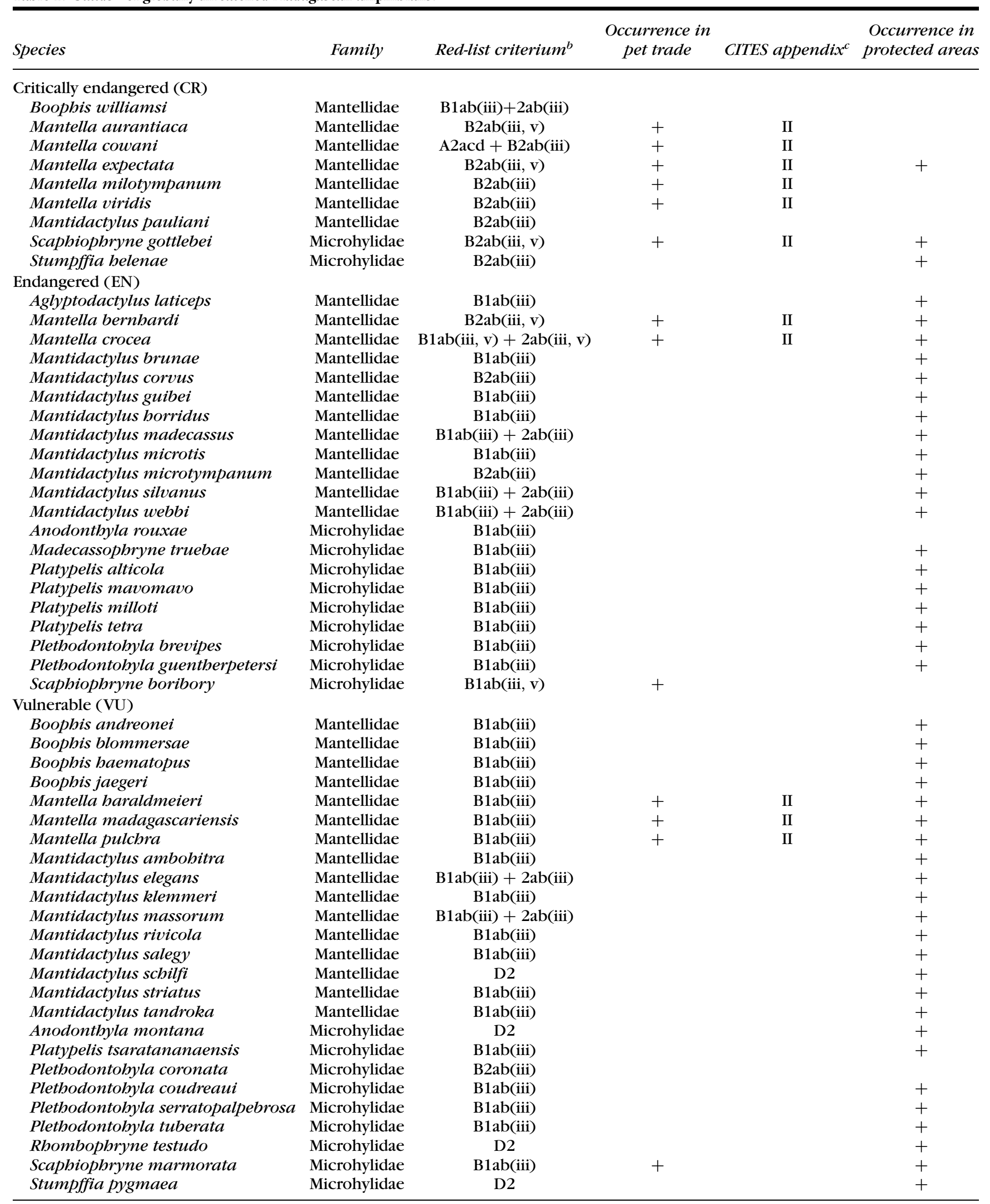

\footnotetext{
${ }^{a}$ Status based on IUCN (2001) criteria.

${ }^{b}$ Criteria coding defined in IUCN (2001) (also available from http://www.redlist.org/info/categories_criteria2001.html\#critical).

${ }^{c}$ CITES, Convention of International Trade of Endangered Species of Wild Fauna and Flora.
} 
Table 2. Malagasy frog species classified as near threatened, least concern, and data deficient.

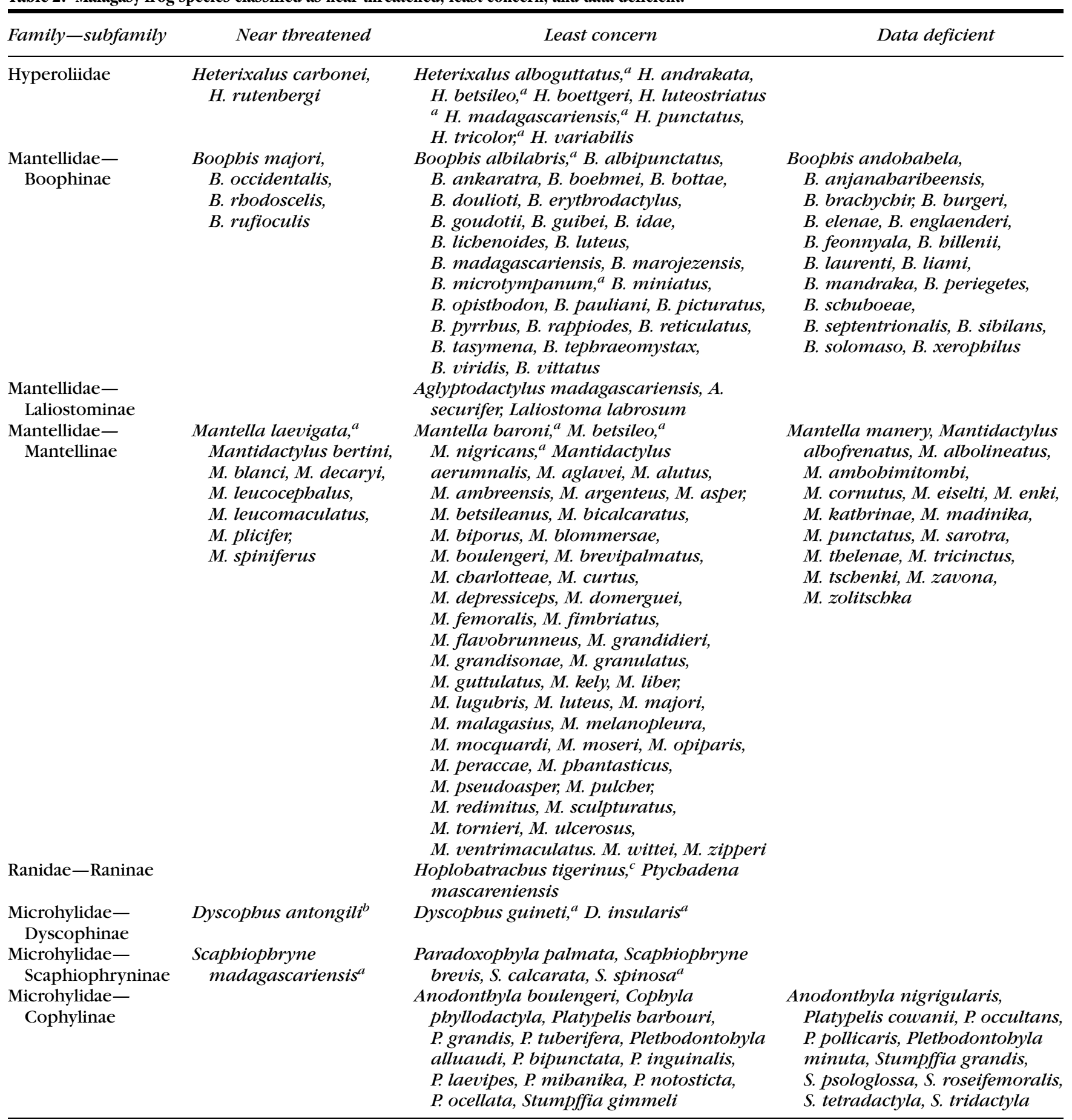

${ }^{a}$ Species in the pet trade.

${ }^{b}$ Species included in CITES Appendix I.

'species included in CITES Appendix II and introduced from southeast Asia.

aurantiaca can be high within just a few hectares. This species lives in damp swamp forests usually associated with Pandanus screw pines (Vences et al. 1999). The extent of its forest habitat is declining, and overharvesting for trade may have reduced some of the existing populations. M. aurantiaca has a narrow distribution in east- central Madagascar centered in the Torotorofotsy area and the Andranomena Forest (at 920-960 m) (Vences et al. 2004). In 2001 much of the forest bordering the Torotorofotsy areas, probably including some of the remaining habitat suitable for Mantella, was burned in a large forest fire (Vences et al. 2004). The area did not appear to 


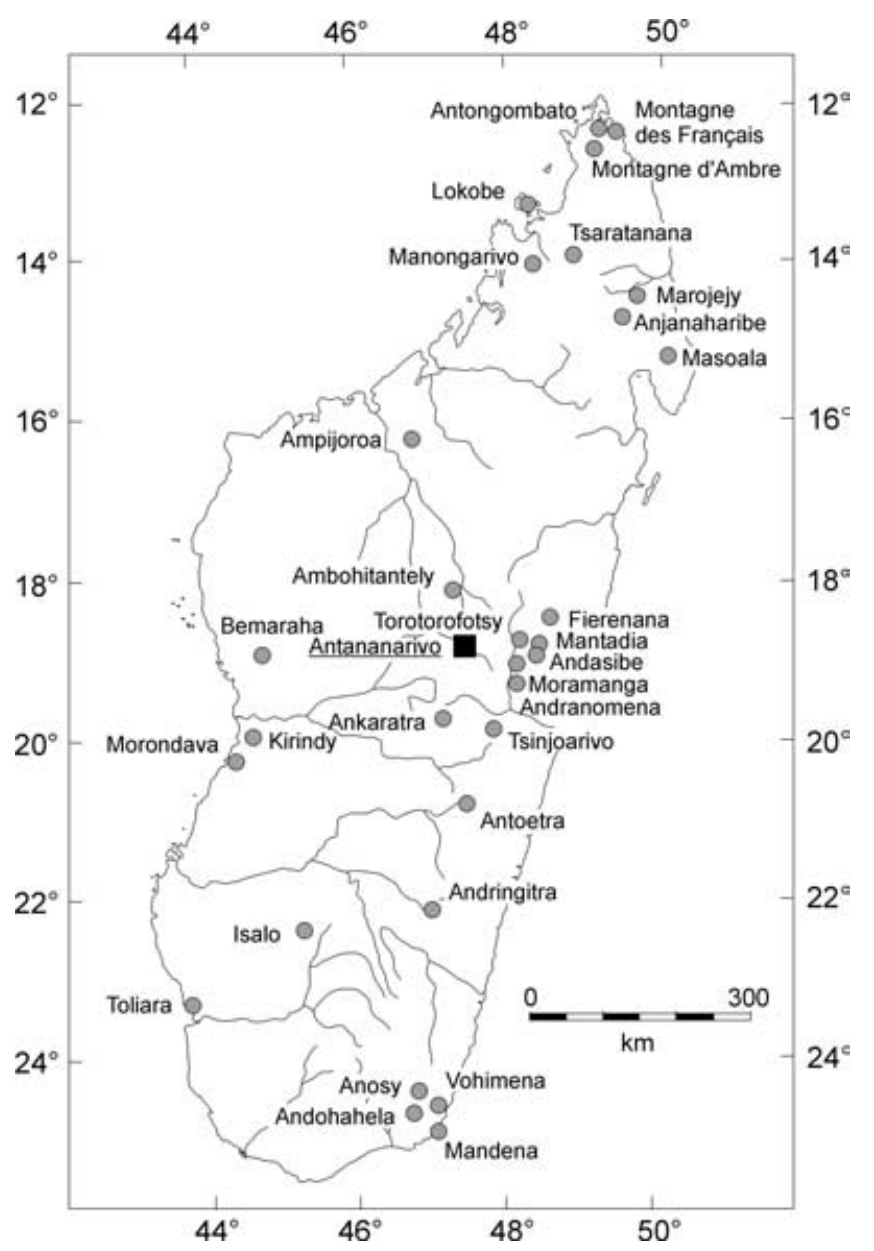

Figure 1. Map of Madagascar, with the localities cited in the text. Square is capital city.

be heavily affected, and 3 years later Mantella were still common (M.V., personal observation). This species was kept in about 35 zoological gardens and other institutions and is commonly bred in captivity (Glaw et al. 2000). A management plan to ensure a controlled and sustainable trade through the establishment of a trade quota is being developed. M. aurantiaca is locally extremely abundant, and the collecting of specimens for the pet trade has not had a visible effect on populations.

We categorized Mantella cowani as CR based on its AOO of $<10 \mathrm{~km}^{2}$. A drastic population decline occurred recently, as deduced from a dramatic reduction in its distribution and in the number of mature adults (Andreone $\&$ Randrianirina 2003). The fact that this decline followed a period of increased exploitation for the international pet trade suggests that populations were overcollected, resulting in a population crash. Although its complete distribution is unknown, $M$. cowani appears to be limited to unprotected High Plateau sites of east-central Madagascar near Antoetra and Tsinjoarivo (at 1000-2000 m). It is a terrestrial frog that lives along streams in highland moors, in areas virtually without forest cover that are reg- ularly subjected to fire. Ongoing field research (F.A., unpublished) revealed that the surviving populations are now often composed of just a few individuals, which are difficult to detect. At a single site next to Antoetra we ascertained the existence of hybrids with M. baroni (F. A., unpublished). A moratorium on the export of $M$. cowani was implemented in 2003.

Mantella expectata was categorized as CR based on its EOO of $<100 \mathrm{~km}^{2}$. M. expectata occurs mainly in syntopy with Scapbiopbryne gottlebei, and the same threats affect both species. Recent surveys revealed that $M$. expectata is present in several locations around the Isalo Massif (at 700-1000 m). Records from near Toliara (Busse \& Böhme 1992) were probably erroneous (Vences et al. 1999). Records from Morondava region and Mandena (Glaw \& Vences 1994) are unreliable because no voucher specimens or recent field surveys document the species in these areas. At Isalo, $M$. expectata is sometimes abundant next to seasonal streams, and in wet canyons sometimes it is associated with narrow gallery forest. This species appears to be locally abundant and is actively sought for the pet trade, and during the rainy season up to several thousand specimens are collected. Sapphire mining activities and related habitat alteration in the vicinity are also possible threats.

We categorized Mantella milotympanum as CR because its AOO is $<10 \mathrm{~km}^{2}$, its distribution is severely fragmented, and the extent of its forest habitat in east-central Madagascar is declining. The species is known in a few unprotected locations in east-central Madagascar near Fierenana (at 900-1000 m). It is locally common in gallery forest around swamps and in seasonally flooded forest. Its habitat is receding because of subsistence agriculture, timber extraction, charcoal manufacture, livestock grazing, and fires.

Mantella viridis was categorized as CR because its AOO is $<10 \mathrm{~km}^{2}$, its distribution is fragmented, and the size and quality of its habitat continue to decline. It occurs in unprotected sites at the Montagne des Français in northern Madagascar and in the Antongombato Massif south of Antsiranana (at 50-300 m), where it is locally abundant. $M$. viridis is typical of deciduous dry forest associated with limestone landscape, usually occurring near temporary brooks and streams. Recent observations confirmed its presence in degraded habitats with good vegetational cover, which provides higher humidity and shade than adjacent nonvegetated areas. Because forest loss frequently leads to permanent drying of smaller streams, however, reduction of natural habitats of this species is a serious concern. The known localities are subject to fires, selective logging, firewood collection, and livestock grazing.

Mantidactylus pauliani was categorized as CR because its AOO is $<10 \mathrm{~km}^{2}$, and its only known population is in a single unprotected site at about $2200 \mathrm{~m}$ in the Ankaratra Massif (Vences et al. 2002a). Like Boophis 

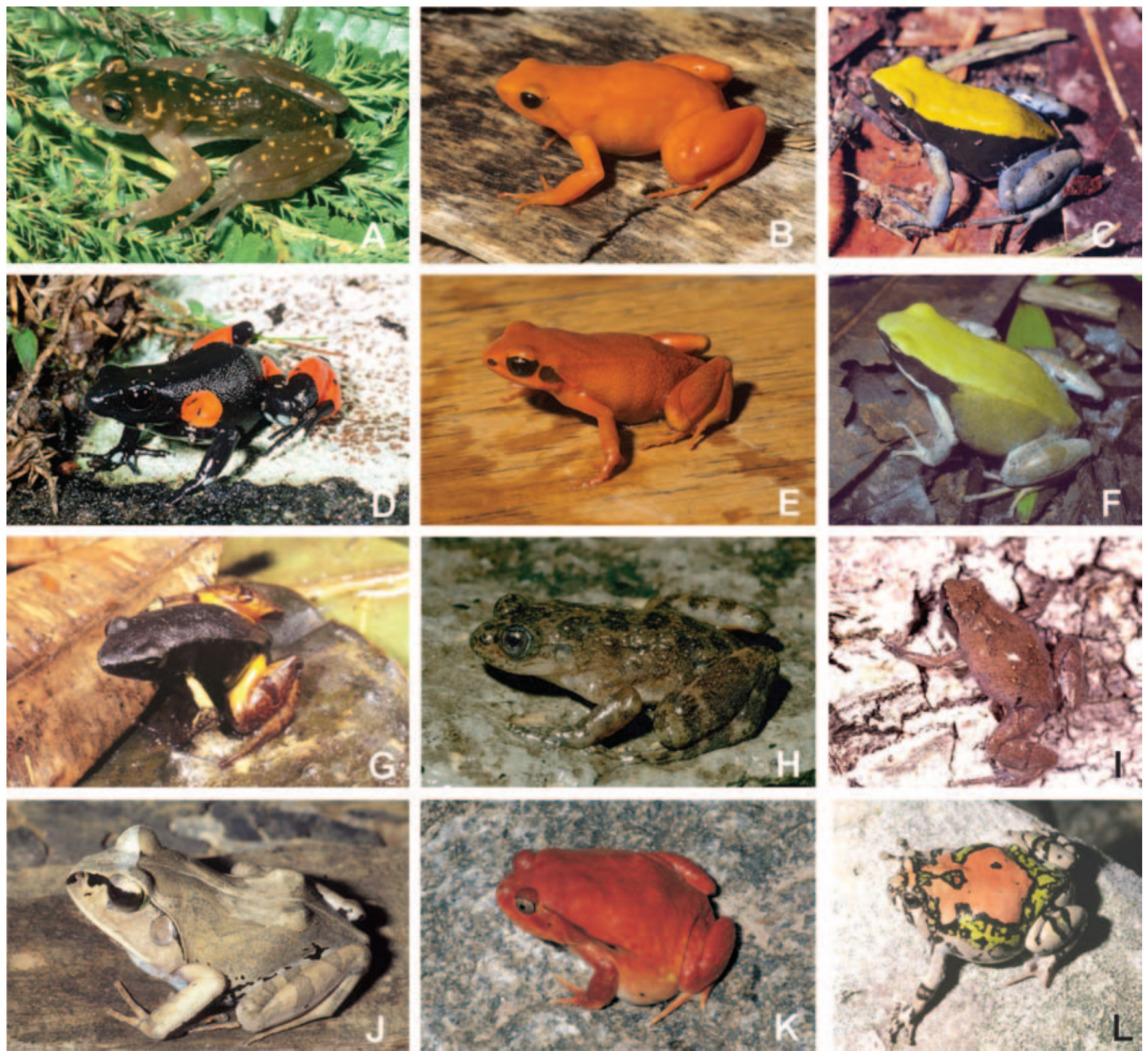

Figure 2. The nine critically endangered frog species of Madagascar, two endangered species, and the CITES Appendix I listed Dyscophus antongili. (a) Boophis williamsi, Ankaratra Massif (CR) (photo by M. Vences); (b) Mantella aurantiaca, Andranomena (CR) (photo by M. Vences); (c) Mantella expectata, Ilakaka (CR) (photo by $F$ Andreone); (d) Mantella cowani, Soamazaka, Antoetra (CR) (photo by F. Andreone); (e) Mantella milotympanum, Fierenana (CR) (photo by M. Vences); $(f)$ Mantella viridis, Montagne des Français (CR) (photo by C. J. Raxworthy); (g) Mantella bernhardi, Tolongoina region (EN) (photo by F. Andreone); (b) Mantidactylus pauliani, Ankaratra Massif (CR) (photo by M. Vences); (i) Stumpffia helenae, Ambohitantely (CR) (photo by D. Vallan); $(j$ ) Aglyptodactylus laticeps, Kirindy Forest (EN) (photo by F. Glaw); (k) Dyscophus antongili, Maroantsetra (NT) (photo by M. Vences); (l) Scaphiophryne gottlebei, Ilakaka (CR) (photo by F. Andreone). Abbreviations: CR, critically endangered; $E N$, endangered; $N T$, near threatened.

williamsi, this Mantidactylus is rarely encountered, and presumably lived originally in montane rainforest but is now known only along a single stream and in highelevation grassland with relict forests. The main threats to the habitat are fire, overgrazing, and expanding potato farming. Pollution and sedimentation of the streams as a result of agriculture and mining are observed in the area.

We categorized Scaphiophryne gottlebe $i$ as CR because its EOO is $<100 \mathrm{~km}^{2}$. All records for this species are from a few areas within the Isalo Massif (at 700-1000 m). It 

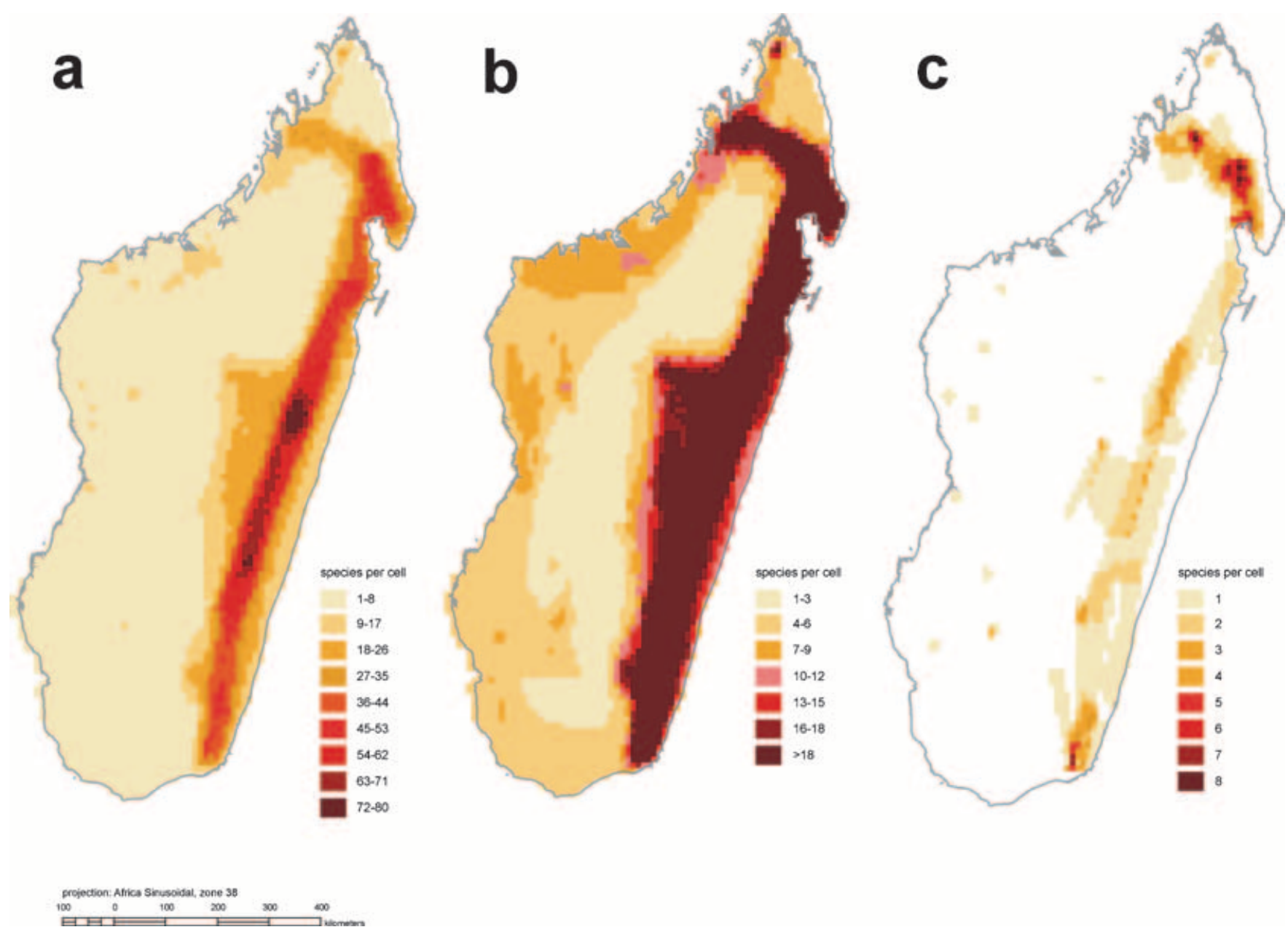

Figure 3. Amphibian species diversity in Madagascar: (a) distribution based on overlaying the estimated distributions of all species described or in press up to December 2003; (b) distribution of total diversity with an emphasis on the species richness in the less diverse western regions (grid cells with $>18$ species shaded alike to emphasize and permit greater discrimination among areas with fewer species); (c) distribution of species assigned IUCN categories of threat during the Global Amphibian Assessment workshop (critically endangered, endangered, or vulnerable).

appears to be a localized frog, although it is abundant in the humid canyons where it usually lives. The extent and quality of its habitat continue to decline, and it is subject to overcollecting for the pet trade. Other threats are similar to those affecting Mantella expectata, with which it is syntopic.

Stumpffia belenae was categorized as CR because it is known only from two forest fragments at $1500 \mathrm{~m}$ within the Réserve Spéciale d'Ambohitantely in central Madagascar (Vallan 2000a). Its $\mathrm{AOO}$ is $<10 \mathrm{~km}^{2}$, and the extent of its habitat is declining because of fire, wood cutting, and overgrazing. The size of the Ambohitantely forest has been shrinking since the nineteenth century (Langrand \& Wilmé 1997), and between 1995 and 1997 this degradation increased. Since 2002 the situation has worsened: fires have encroached on the edges of the remaining fragments, and recently 30 ha of a parcel burned (D.V., unpublished).

\section{Areas of Diversity and Distribution of Threatened Species}

The highest-diversity areas for the amphibian fauna were in eastern and northeastern Madagascar (Fig. 3a). These regions had 64-82 species per grid cell. The arid western and southern areas associated with deciduous dry or spiny forests had still fewer frog species.

Because the species diversity in the eastern forests is much greater than in other regions, we successively evaluated the frog species with more coarse-grained species richness categories and combined all areas with more than 18 species into a single category (Fig. 3b). This approach permitted a finer discrimination among areas in western Madagascar with generally low species diversity, thus permitting identification of areas of dry forests worthy of special attention. The northwestern sector appeared more diversified than the other western areas. The 
areas of highest diversity in the west coincided with some protected forest fragments (e.g., Ampijoroa, Bemaraha, Kirindy, and Isalo). Patterns of species richness on the central High Plateau paralleled the general trend toward greater richness in the east and lower richness in the west (Fig. 3a, b). In fact, the eastern portion of the High Plateau was much richer in species than its remaining portion. The flora and fauna of the eastern area of the plateau are characterized by a species composition that is more similar to the eastern rainforests than regions farther west.

The overlay of the distributions of highly threatened species showed that many of them fall primarily in the northern and northeastern highlands (Fig. 3c), including the protected areas of Masoala and MarojejyAnjanaharibe, Tsaratanana, Manongarivo, Lokobe (Nosy Be), and Montagne d'Ambre. A second concentration point of threatened species occurred in the extreme southeast, in humid forests of the Anosy and Vohimena mountains. A third group of threatened species occurred on the central massifs of Ankaratra and Andringitra. Other areas with important concentrations of threatened species are in the vicinity of Moramanga (for many species of Mantella) and at Isalo Massif (for Mantella expectata and Scaphiophryne gottlebei).

\section{Discussion}

\section{Present Extinction Status of Amphibian Fauna}

An interesting result of our evaluation is that, with the exception of two species (Anodontbyla rouxae and Mantidactylus ambobimitombi), the existence of all species of Malagasy frogs described since the nineteenth century was confirmed during the last 15 years in our own fieldwork. This suggests that Madagascar has so far escaped large-scale, recent amphibian extinctions such as those reported in many other areas of the world (e.g., Central America, Australia, and the United States) (Heyer et al. 1988; Alexander \& Eischeid 2001; Young et al. 2001). We currently suspect our failure to confirm Anodontbyla rouxae (in the Anosy Mountain chain in southeastern Madagascar) and Mantidactylus ambobimitombi (in the High Plateau) is a consequence of insufficient field research in these regions.

Species rarefaction of Malagasy amphibians is due mainly to habitat loss. Extensive habitat degradation and forest destruction, however, have not yet caused perceivable extinctions of amphibian species. We believe the reason for this is that amphibian species are able to survive in small forest areas within comparatively small populations. Nonetheless, habitat alteration can quantitatively affect the species composition of communities over brief time scales (Andreone 1994; Vallan 2000b, 2002). Although we are not aware of documented species extinctions, we cannot exclude the possibility that the extensive clearing of the High Plateau may have already caused the extinc- tion of (unknown) locally endemic species (Raxworthy \& Nussbaum, 1996; Raxworthy 2003).

\section{Protected Areas and Endangered Species}

Forty-five threatened species of frogs were found in protected areas. Of the nine CR species, only three (Stumpffia belenae, Scapbiopbryne gottlebei, and Mantella expectata) currently occur within a protected area (Réserve Spécial d'Ambohitantely and Parc National de l'Isalo), and therefore benefit from legal protection. $M$. aurantiaca occurs at a site (Torotorofotsy Marsh) that soon will become legally protected as a Ramsar site (ANGAP 2001). Of the threatened species in other categories (EN, VU; Table 1), three are not known from protected areas: Anodonthyla rouxae, Pletbodontobyla coronata, and Scapbiopbryne boribory. Their threatened status is thus worthy of special attention in defining new protected areas.

The CR species most at risk of extinction (Mantella cowani, Boophis williamsi, Mantidactylus pauliani, and Stumpffia belenae) live on the High Plateau, where much of the original habitat has been lost because of extensive slash-and-burn agricultural practices and erosion. These species survive in only a few isolated sites surrounded by landscapes hostile to amphibians (e.g., secondary savannahs and spoiled soils) that represent dispersal barriers between populations. Degradation of montane habitats in the High Plateau may also affect other species classified as endangered: Mantidactylus guibei, M. madecassus, M. microtis, Anodontbyla rouxae, Platypelis alticola, and Pletbodontobyla guentherpetersi.

The remaining threatened species (mostly in EN and VU categories) occur in the eastern and northwestern rainforest belt at low- to mid-elevation areas ( $\leq 1000 \mathrm{~m})$ : Mantella bernhardi, Mantidactylus brunae, M. borridus, M. microtympanum, M. silvanus, M. webbi, Madecassopbryne truebae, Platypelis milloti, Pletbodontobyla brevipes, and Scapbiopbryne boribory. They all have restricted ranges and some are rare or localized, although sometimes locally abundant.

\section{Data-Deficient Species and Undersampled Areas}

Forty-six species (20.6\% of the known amphibians) were categorized as data deficient (DD). For these species it was difficult to provide reliable conservation recommendations, except based on ecological parameters (e.g., Andreone \& Luiselli 2003). The DD list includes mostly recently described species, for which geographic distributions are still poorly known, that in many cases are still restricted to a single forest site (e.g., Boopbis feonnyala, B. liami, and B. solomaso) (Glaw et al. 2001; Vallan et al. 2003). Field research is therefore badly needed to update and clarify their status in the wild. 
The DD list also includes species whose taxonomy and identifications are provisional. Many of these are, in reality, assemblages of closely related taxa, and their systematic revision will result in the descriptions of new species. The IUCN listing will therefore need to be updated once their systematic status is resolved. Many of the DD frogs are cophyline microhylids, for which the taxonomy and even the specific attribution are often dubious (Andreone et al. 2005). For example, within this group we lack sufficient systematic resolution of Platypelis cowani, P. pollicaris, Pletbodontobyla minuta, Stumpffia psologlossa, and $S$. tetradactyla to provide a reliable conservation assessment. Similar problems pertain to species of Boophis and Mantidactylus (e.g., B. brachychir and M. punctatus).

Most of the research activity in Madagascar has been carried out in areas that are already known for high species diversity (e.g., Andasibe) or have good vegetational cover (e.g., Masoala, Marojejy). There are other areas that are undersampled, such as large portions of southeastern Madagascar, especially between the Andringitra Massif and the Anosy Mountains. Especially little is known of areas that are not yet legally protected. In these areas the abundance and diversity of amphibians can be rapidly assessed; therefore, amphibians here are well suited for biological assessment surveys (Andreone \& Randrianirina 2000). Indeed, the analysis of amphibian diversity in some unprotected areas was the basis for their upgrading and for integrations of protected networks, such at Betaolana between Anjanaharibe-Sud and Marojejy (Andreone et al. 2000).

Another area where the pattern of amphibian diversity is almost unknown is the central High Plateau. We believe this area was originally less rich in species than the eastern rainforest escarpment. Now heavy anthropogenic pressure has resulted in an almost total deforestation of the area and caused further impoverishment, with presence of savannah-like grasslands and eroded lands. The residual small forest fragments and small vegetation belts along the streams and rivers and a few high-elevation moors are the only surviving natural habitats. These forest islands may harbor undescribed species.

Other undersampled areas for amphibians include the western deciduous forests, which are heavily logged; the dry area between Montagne d'Ambre and the MarojejyMasoala complex in northeastern Madagascar; and the lowlands of the east coast south of Toamasina, which is largely deforested. A program of survey work in these areas is therefore urgent.

\section{International Trade Impacts and CITES Listings}

Several CR and EN species are in demand for international trade. The genus with the highest number of threatened species is Mantella, with 10 out of the 15 described species, followed by Scaphiophryne, with 3 out of 7 spe- cies. Not all species of these genera are highly sought after by the pet trade. For example, some less attractive species of Mantella (e.g., M. betsileo, M. bernhardi, and M. haraldmeieri) are only occasionally collected for commercial purposes and are mainly threatened by habitat modifications (Rabemanjara et al. 2005). Other species (e.g., $M$. nigricans, M. baroni, and M. pulchra) are more regularly seen in commercial markets but are not especially threatened at present because they have wide distributions.

A general problem concerning traded species is the lack of information about the effect of commercial collecting on the integrity of populations. Nonetheless, it is our conviction that when ecological requirements and sensitivity to habitat alteration are combined with intensive capture, the species in question become more endangered. This is the case for Mantella cowani, whose small distribution, concurrent habitat alteration, and collection combine to make this one of the most threatened frog species of Madagascar (Andreone \& Randrianirina 2003). In other cases, such as for Mantella aurantiaca and Scapbiophryne gottlebei, populations are still large enough to sustain some well-regulated commercial collecting.

The tomato frog, Dyscopbus antongili, is the only species of Malagasy amphibian currently listed in CITES, Appendix I (since 1987). Its inclusion implies a complete ban on trade because large quantities of this attractive species were formerly exported. Our observations in the coastal town of Maroantsetra indicate the tomato frog is moderately common, living partly burrowed in sandy soil and reproducing in sewage ditches (Glaw \& Vences 1994), and that trade does not constitute a current threat. Habitat alteration and the uncertainty of its occurrence in protected areas (e.g., no reliable records within the Masoala National Park), however, pose some problems for survivorship of the largest populations. Surprisingly, except for a few notes (e.g., Pintak 1987), little is known about this species. The tomato frog was previously categorized as vulnerable by IUCN (Raxworthy \& Nussbaum 2000), whereas we classified it as near threatened. The tomato frog is regularly bred in captivity (De Vosjoli \& Mailloux 1990), and this may constitute an advantage with respect to other species because the trade could be supplied with captive-bred rather than wild individuals. Instead, attention should be paid to the situation regarding D. guineti, which has become more subject to capture as a consequence of the inclusion of D. antongili in Appendix I.

\section{Proposals for Amphibian Conservation}

The CR frog species could be used to catalyze amphibian conservation action in Madagascar, where a "flagship approach" may be useful. In particular, the establishment of Mantella sanctuaries would afford protection for Mantella and other amphibian species. We suggest that at least 
some of these areas be integrated into a protected-area network. A possible sanctuary in central-eastern Madagascar might include the Torotorofotsy wetlands and nearby areas, where $M$. aurantiaca, $M$. crocea, $M$. baroni, and M. pulchra occur. At least some areas here, with a high diversity of CR species, fall within areas of high overall amphibian diversity (Fig. 3). This area and the forests surrounding Andasibe are known for their high frog diversity (>100 species, F.G. and M.V., unpublished) and for high levels of biological diversity overall.

Moreover, some other areas that host threatened species are not yet included in the protected-area network. These are, for example, Fierenana, which contains typical habitat for Scapbiopbryne boribory and Mantella milotympanum, and Montagne des Français, which contains typical habitat for Mantella viridis. General habitat conservation in these areas will aid in the protection of the CR species, and protection of a CR species (such as $M$. aurantiaca at Torotorofotsy) will help preserve a habitat that otherwise would be subject to degradation or deforestation.

Because Mantella cowani is present only in relict natural habitats on the High Plateau, where the overall species diversity is low, a special effort should be made to preserve high-elevation moors and heaths where the species occurs (Raxworthy \& Nussbaum 1996). This could be at some sites next to Antoetra, where the species is present and where the major haplotype richness has been confirmed (Chiari et al. 2005). Banning trade in M. cowani and investigating whether the species could be reliably bred in captivity to generate captive stocks should be associated with efforts to get more precise data on its distribution, population abundance, and genetic isolation. This approach must be carefully managed because the species has not yet been bred successfully in captivity.

A major concern is the conservation of other plateau species such as Boophis williamsi and Mantidactylus pauliani that occur at a few unprotected sites in areas with comparatively low species diversity. We suggest that further research be conducted on these species and that known distribution areas will benefit from special attention.

A complementary conservation approach is necessary to identify unprotected areas with high amphibian diversity. Areas thus identified can then be proposed as amphibian reserves. Some of these areas are coincident with Mantadia-Analamazaotra and the Torotorofotsy wetlands and Fierenana forest. Others are around Andohahela, the more northerly Anosy-Vohimena Mountains, and the northern corridor forests that link the four reserves of Masoala, Anjanaharibe-Sud, Marojejy, and Tsaratanana.

Some of these reserves already have well-established conservation programs, and it should be possible to include long-term monitoring programs to assess potential population changes in sensitive taxa or communities. We also envision interesting prospects for using new distri- bution modeling approaches in Madagascar (Raxworthy et al. 2003). This would allow us, for example, to map the distributions of amphibian species currently excluded from protected areas and thus make recommendations for new protected areas that maximize unprotected amphibian inclusion.

The inclusion of some species in CITES listings may present a reliable method for monitoring and thereby protecting species in the commercial trade. With the exception of the tomato frog, most of the other traded species are in Appendix II. The only species in trade that are not included on any list and are classified as EN or VU are Scapbiopbryne boribory and $S$. marmorata. These two species should be incorporated in CITES Appendix II because of their attractiveness and high market demand. Regulation of their exportation would allow monitoring for this and other traded and threatened species.

\section{Acknowledgments}

Many people helped us during our fieldwork and other efforts in surveying the biodiversity of Madagascar: B. Andriamihaja, G. Aprea, J. L. Behler, O. Behra, P. Bora, Y. Chiari, E. J. Edwards, S. M. Goodman, F. Mattioli, S. Mahaviasy, M. Puente, F. C. E. Rabemanjara, N. Rabibisoa, L. Raharivololoniaina, E. Rajeriarison, D. Rakotomalala, E. Rakotomavo, D. M. Rakotondramanana, D. Rakotondravony, J. B. Ramanamanjato, O. Ramilijaona, O. Ramilison, H. Randriamahazo, R. D. Randrianiaina, J. E. Randrianirina, A. P. Raselimanana, R. Razafindrasoa, A. and A. Razafimanantsoa, G. Schneider, M. O. Sohantenaina, M. Thomas, D. R. Vieites, P. Talata, and P. C. Wright. The fieldwork was conducted under agreements with the Ministère des Eaux et Forêts and the Association Nationale pour la Gestion des Aires Protegées (ANGAP), which provided the necessary authorizations. The Global Amphibian Assessment was primarily funded by the Moore Family Foundation, and the Gordon and Betty Moore Foundation. The GAA workshop on the amphibians of Madagascar was funded by Conservation International (Madagascar). This study was supported by grants of the following institutions: BIOPAT Foundation, Chicago Zoological Society, Declining Amphibian Population Task Force, Deutsche Gesellschaft für Herpetologie und Terrarienkunde, Deutsche Forschungsgemeinschaft, Deutscher Akademischer Austauschdienst, Douroucouli Foundation, Earthwatch, MacArthur Foundation, Madagascar Fauna Group, MAVA Foundation, Nando Peretti Foundation, National Amphibian Conservation Center, National Geographic Society, National Science Foundation, Netherlands Organisation for Scientific Research, Swiss Academy of Sciences, U.S. Department of State, Volkswagen Foundation, Wildlife Conservation Society, and World Wide Fund for Nature. Special thanks to the Museo Regionale di Scienze Naturali 
(Torino) and Conservation International (Madagascar) for having kindly and generously supported the publication of the color maps and plates. Many thanks also to D. Fischman and S. Krogh of Conservation International, who provided much-appreciated help in the spatial analysis of the species range maps. A. P. Raselimanana, an unknown referee, F. Hawkins, and G. Meffe provided useful comments and criticisms on an earlier draft of this paper.

\section{Literature Cited}

Alexander, M. A., and J. K. Eischeid. 2001. Climate variability in regions of amphibian declines. Conservation Biology 15:930-942.

Andreone, F. 1994. The amphibians of Ranomafana rain forest, Madagascar-preliminary community analysis and conservation considerations. Oryx 28:207-214.

Andreone, F. 2003. Mantellidae: Mantidactylus. Pages 910-913 in S. M. Goodman and J. P. Benstead, editors. The natural history of Madagascar. University of Chicago Press, Chicago.

Andreone, F., and L. M. Luiselli. 2003. Conservation priorities and potential threats influencing the hyper-diverse amphibians of Madagascar. Italian Journal of Zoology 70:53-63.

Andreone, F., and J. E. Randrianirina. 2000. Biodiversity, rainforests and herpetological communities in Madagascar: what about differences between amphibians and reptiles? Pages 217-228 in W. Lourenço and S. M. Goodman, editors. Diversity and endemism in Madagascar. Mémoires de la Société de Biogéographie, Paris.

Andreone, F, and J. E. Randrianirina. 2003. It's not carnival for the harlequin mantella! Urgent actions needed to conserve Mantella cowani, an endangered frog from the High Plateau of Madagascar. Froglog 59:1-2.

Andreone, F., J. E. Randrianirina, P. D. Jenkins, and G. Aprea. 2000. Species diversity of Amphibia, Reptilia and Lipotyphla at Ambolokopatrika, a rainforest between Anjanaharibe-Sud and Marojejy massifs, NE Madagascar. Biodiversity and Conservation 9:15871622.

Andreone, F., M. Vences, D. R. Vieites, F. Glaw, and A. Meyer. 2005. Recurrent ecological adaptations revealed through a molecular analysis of the secretive cophyline frogs of Madagascar. Molecular Phylogenetics and Evolution 34: 315-322.

ANGAP (Association National pour la Gestion des Aires Protegées). 2001. Plan de gestion du réseau national des aires protégées de Madagascar. ANGAP and Ministère de l'Environnement, Antananarivo, Madagascar (in French).

Behra, O., and C. J. Raxworthy. 1991. Exportation des amphibiens de Madagascar. Interet, danger et perspectives d'avenir. Circalytes 5:45-49 (in French)

Blommers-Schlösser, R. M. A. 1979. Biosystematics of the Malagasy frogs. II. The genus Boophis (Rhacophoridae). Bijdragen tot der Dierkunde 49:261-312.

Blommers-Schlösser, R. M. A., and C. P. Blanc. 1991. Amphibiens (première partie). Faune de Madagascar 75 (1):1-380 (in French).

Busse, K., and W. Böhme. 1992. Two remarkable frog discoveries of the genera Mantella (Ranidae: Mantellinae) and Scaphiophryne (Microhylidae: Scaphiophryninae) from the west coast of Madagascar. Revue française d'Aquariologie 19:57-64.

Chiari, Y., F. Andreone, J. E. Randrianirina, M. Vences, and A. Meyer. 2005. Genetic variation of an endangered Malagasy frog, Mantella cowani, and its phylogeographic relationships to the widespread Mantella baroni. Conservation Genetics: in press.

Daly, J. W., N. R. Andriamaharavo, M. Andriantsiferana, and C. W. Myers. 1996. Madagascan poison frogs (Mantella) and their skin alkaloids. American Museum Novitates 3177:1-34.

De Vosjoli, P., and R. Mailloux. 1990. Breeding on thin ice: the husbandry and propagation of the Malagasy tomato frogs, Dyscophus antongilii and D. insularis. Pages 181-193 in M. J. Uricheck, editor. Proceedings of the 13th international herpetological symposium. International Herpetological Symposium, Inc., Salt Lake City, Utah.

ESRI (Environmental Systems Research Institute) 2000. ArcView GIS 3.2a. ESRI, New York.

Ganzhorn, J. U., B. Rakotosamimanana, L. Hannah, J. Hough, L. Iyer, S. Olivieri, S. Rajaobelina, C. Rodstrom, and G. Tilkin. 1997. Priorities for biodiversity conservation in Madagascar. Primate Report 48: $1-81$.

Glaw, F, and M. Vences. 1994. A fieldguide to the amphibians and reptiles of Madagascar, including freshwater fish and mammals. Second edition. Vences und Glaw Verlag, Cologne.

Glaw, F. and M. Vences. 2003. Introduction to amphibians. Pages 883898 in S. M. Goodman and J. P. Benstead, editors. The natural history of Madagascar. University of Chicago Press, Chicago.

Glaw, F., K. Schmidt, and M. Vences. 2000. Nachzucht, Juvenilfärbung und Oophagie von Mantella laevigata im Vergleich zu anderen Arten der Gattung (Amphibia: Ranidae). Salamandra 36:1-24 (in German).

Glaw, F., M. Vences, F. Andreone and D. Vallan. 2001. Revision of the Boophis majori group (Amphibia: Mantellidae) from Madagascar, with descriptions of five new species. Zoological Journal of the Linnean Society 133:495-529.

Green, G. and R. W. Sussman. 1990. Deforestation history of the eastern rainforests of Madagascar from satellite images. Science 248:212215.

Heyer, W. R., A. S. Rand, C. A. Goncalvez da Cruz, and O. L. Peixoto. 1988. Decimations, extinctions, and colonizations of frog populations in southeast Brazil and their evolutionary implications. Biotropica 20:230-235.

IUCN (World Conservation Union). 2001. IUCN red list categories. Version 3.1. Species Survival Commission, IUCN, Gland, Switzerland, and Cambridge, United Kingdom.

Kosuch, J., M. Vences, A. Dubois, A. Ohler, and W. Böhme. 2001. Out of Asia: mitochondrial DNA evidence for an oriental origin of tiger frogs, genus Hoplobatrachus. Molecular Phylogenetics and Evolution 21:398-407.

Langrand, O., and L. Wilmé. 1997. Effects of forest fragmentation on extinction patterns of the endemic avifauna on the Central High Plateau of Madagascar. Pages 280-305 in S. M. Goodman and B. D. Patterson, editors. Natural change and human impact in Madagascar. Smithsonian Institution Press, Washington D.C.

Pintak, T. 1987. Zur Kenntnis des Tomatenfrosches Dyscophus antongili (Grandidier, 1877 [Anura: Microhylidae]). Salamandra 23:106-121 (in German).

Rabemananjara, F., P. Bora, J. E. Cadle, F. Andreone, E. Rajeriarison, P. Talata, F. Glaw, M. Vences, and D. R. Vieites. 2005. New records, distribution and conservation of Mantella bernhardi, an endangered frog species from south-eastern Madagascar. Oryx 39:339-342.

Raxworthy, C. J. 2003. Introduction to the reptiles. Pages 934-949 in S. M. Goodman and J. P. Benstead, editors. The natural history of Madagascar. University of Chicago Press, Chicago.

Raxworthy, C. J., and R. A. Nussbaum. 1996. Montane amphibian and reptile communities in Madagascar. Conservation Biology 10:750756.

Raxworthy, C. J., and R. A. Nussbaum. 2000. Extinction and extinction vulnerability of amphibians and reptiles in Madagascar. Amphibian and Reptile Conservation 2:15-23.

Raxworthy, C. J., E. Martinez-Meyer, N. Horning, R. A. Nussbaum, G. E. Schneider, A. Ortega-Huerta, and A. T. Peterson. 2003. Predicting distributions of known and unknown reptiles species in Madagascar. Nature 426:837-841.

Rodrigues A. S. L., et al. 2004. Effectiveness of the global protected area network in representing species diversity. Nature 428:640-642.

Stuart, S. N., J. S. Chanson, N. A. Cox, B. E. Young, A. S. L. Rodrigues, D. L. Fischman, and R. W. Waller. 2004. Status and trends of amphibian declines and extinctions worldwide. Science 306:1783-1786. 
Vallan, D. 2000a. A new species of the genus Stumpffia (Amphibia: Anura: Microhylidae) from a small forest remnant of the central high plateau of Madagascar. Revue Suisse de Zoologie 107:835-841.

Vallan, D. 2000b. Influence of forest fragmentation on amphibian diversity in the nature reserve of Ambohitantely, highland Madagascar. Biological Conservation 96:31-43.

Vallan, D. 2002. Effects of anthropogenic environmental changes on amphibian diversity in the rainforests of eastern Madagascar. Journal of Tropical Ecology. 18:725-742.

Vallan, D. 2003. Consequences of rain forest fragmentation for herpetofauna: a case study from Ambohitantely. Pages 899-907 in S. M. Goodman and J. P. Benstead, editors. The natural history of Madagascar. The University of Chicago Press, Chicago.

Vallan, D., M. Vences, and F. Glaw. 2003. Two new species of the Boophis mandraka complex (Anura, Mantellidae) from the Andasibe region in eastern Madagascar. Amphibia-Reptilia 24:305-319.

Vallan, D., F. Andreone, V. Raherisoa, and R. Dolch. 2004. Does selective wood exploitation affect amphibian diversity? The case of An'Ala, a tropical rainforest in eastern Madagascar Oryx 38:410-417.

Vences, M., and F. Glaw. 2001. When molecules claim for taxonomic change: new proposals on the classification of Old World treefrogs. Spixiana 24:85-92.
Vences, M., F. Glaw, and W. Böhme. 1999. A review of the genus Mantella (Anura, Ranidae, Mantellinae: taxonomy, distribution and conservation of Malagasy poison frogs. Alytes 17:3-72.

Vences, M., Y. Chiari, L. Raharivololoniaina, and A. Meyer. 2004. High mitochondrial diversity within and among populations of Malagasy poison frogs. Molecular Phylogenetics and Evolution 30:295307.

Vences, M., J. Kosuch, F. Glaw, W. Böhme, and M. Veith. 2003. Molecular phylogeny of hyperoliid treefrogs: biogeographic origin of Malagasy and Seychellean taxa and re-analysis of familial paraphyly. Journal of Zoological and Systematic Evolutionary Research 41:205-215.

Vences, M., F. Andreone, F. Glaw, N. Raminosoa, J. E. Randrianirina, and D. R. Vieites. 2002a. Amphibians and reptiles of the Ankaratra Massif: reproductive diversity, biogeography and conservation of a montane fauna in Madagascar. Italian Journal of Zoology 69:263-284.

Vences, M., F. Andreone, F. Glaw, J. Kosuch, A. Meyer, C. Schaefer, and M. Veith. 2002b. Exploring the potential of life-history key innovation: brook breeding in the radiation of the Malagasy treefrog genus Boophis. Molecular Ecology 11:1453-1463.

Young, B. E., et al. 2001. Population declines and priorities for amphibian conservation in Latin America. Conservation Biology 15 1213-1223.

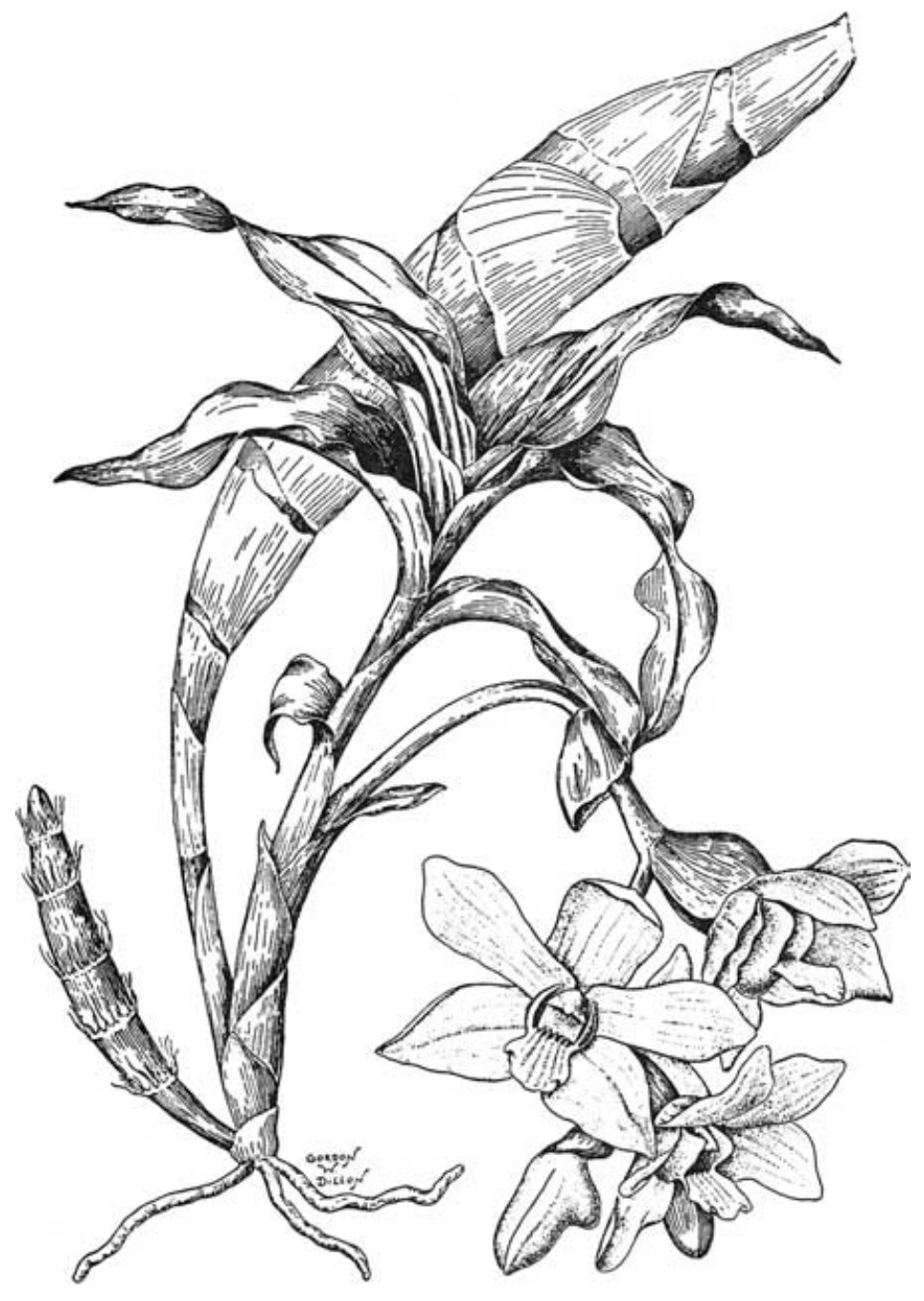

